Revista Brasil. Bot., V.32, n.1, p.177-181, jan.-mar. 2009

Scientific Note/Nota Científica

\title{
Megaspore germination and initial development of Regnellidium diphyllum Lindman (Pteridophyta, Marsileaceae) sporophytes in the presence of cadmium
}

\author{
DENISE A. WUNDER ${ }^{1}$, ANNETTE DROSTE ${ }^{2}$ and PAULO G. WINDISCH ${ }^{3,4}$
}

(received: April 03, 2008; accepted: December 11, 2008)

\begin{abstract}
Megaspore germination and initial development of Regnellidium diphyllum Lindman (Pteridophyta, Marsileaceae) sporophytes in the presence of cadmium). Regnellidium diphyllum has its distribution restricted to Southern Brazil and adjoining localities in Uruguay and Argentina. Currently it is on the list of threatened species of Rio Grande do Sul. The conversion of wetlands into agricultural areas or soil contamination by the introduction of waste products and fertilizers may compromise the establishment and survival of this species. Among the pollutants are heavy metals, such as cadmium $(\mathrm{Cd})$. Megaspores were germinated in liquid culture medium, with concentrations 0 (control), $0.39 ; 0.78 ; 1.56 ; 3.12 ; 6.25 ; 12.5 ; 25 ; 50$ and $100 \mathrm{mg} \mathrm{L}^{-1}$ of $\mathrm{Cd}$, starting from a standard solution of Titrisol ${ }^{\oplus}$ at $1000 \mathrm{mg} \mathrm{L}^{-1}$. The increase of $\mathrm{Cd}$ in the growth medium to $50 \mathrm{mg} \mathrm{L}^{-1}$ resulted in low germinability (58\%), and no germination was observed on $100 \mathrm{mg} \mathrm{L}^{-1}$. In apomictical sporophytes, the growth of primary root and leaf was significantly reduced and no secondary leaf was formed at $\mathrm{Cd}$ concentrations of 12.5 and higher than this. The results indicated that $R$. diphyllum is tolerant to the presence of $\mathrm{Cd}$ up to considerably higher concentrations $\left(0.78 \mathrm{mg} \mathrm{L}^{-1}\right)$ than that normally found in unpolluted aquatic ecosystems $\left(0.01 \mathrm{mg} \mathrm{L}^{-1}\right)$, although the sensitivity to higher concentrations might endanger the establishment and permanence of this species in habitats exposed to contamination with this metal.
\end{abstract}

Key words - ecophysiology, heavy metals, pollution, pteridophytes, reproduction

RESUMO - (Germinação de megásporos e desenvolvimento inicial de esporófitos de Regnellidium diphyllum Lindman (Pteridophyta, Marsileaceae) na presença de cádmio). Regnellidium diphyllum tem sua distribuição restrita ao Sul do Brasil e localidades vizinhas no Uruguai e na Argentina. Atualmente, ela faz parte da lista de espécies ameaçadas do Rio Grande do Sul. A conversão de áreas úmidas em espaços para agricultura ou a contaminação do solo pela introdução de resíduos tóxicos e fertilizantes podem comprometer o estabelecimento e a sobrevivência da espécie. Entre os poluentes, estão metais pesados, como o cádmio (Cd). Megásporos foram germinados em meio de cultura líquido, com concentrações de 0 (controle), 0,$39 ; 0,78 ; 1,56 ; 3,12 ; 6,25 ; 12,5 ; 25 ; 50$ e $100 \mathrm{mg} \mathrm{L}^{-1}$ de Cd, a partir de uma solução padrão de Titrisol ${ }^{\circledR}$ a $1000 \mathrm{mg} \mathrm{L}^{-1}$. O aumento de Cd para $50 \mathrm{mg} \mathrm{L}^{-1}$ no meio de crescimento resultou em baixa germinabilidade (58\%), não sendo observada germinação a $100 \mathrm{mg} \mathrm{L}^{-1}$. Em esporófitos apomíticos, houve redução significativa do crescimento da raiz e da folha primárias e ausência de formação de folha secundária a partir de $12,5 \mathrm{mg} \mathrm{L}^{-1}$ de Cd. Os resultados indicaram que $R$. diphyllum é tolerante à presença de $\mathrm{Cd}$ em concentrações consideravelmente mais altas $\left(0,78 \mathrm{mg} \mathrm{L}^{-1}\right)$ do que aquelas normalmente encontradas em ecossistemas aquáticos não poluídos $\left(0,01 \mathrm{mg} \mathrm{L}^{-1}\right)$, embora a sensibilidade a concentrações mais altas possa ameaçar o estabelecimento e a permanência dessa espécie em habitats expostos à contaminação com esse metal.

Palavras-chave - ecofisiologia, metais pesados, poluição, pteridófitas, reprodução

\section{Introduction}

Ecotoxicologic investigations have made it possible to evaluate the sensitivity and vulnerability of species to

1. Prefeitura Municipal de Augusto Pestana, Secretaria Municipal da Agricultura e Meio Ambiente, Rua da República 96, 98740-000 Augusto Pestana, RS, Brazil.

2. Universidade do Vale do Rio dos Sinos, Avenida Unisinos 950, 93022-000 São Leopoldo, RS, Brazil / Centro Universitário Feevale, RS-239 2755, 93352-000 Novo Hamburgo, RS, Brazil.

3. Universidade Federal do Rio Grande do Sul, Programa de PósGraduação em Botânica, Avenida Bento Gonçalves 9500, 91501970 Porto Alegre, RS, Brazil.

4. Corresponding author: pteridos@gmail.com chemical pollution, and to predict extinction risks in contaminated environments (Espíndola et al. 2003). The different effects of heavy metals on plants indicate the possibility of the potential use of aquatic plants as bioindicators and accumulators of contaminants (Oliveira et al. 2001, Aravind \& Prasad 2005). The selection of plants with the capacity to absorb and metabolize toxic elements opens the possibility of their use for phytoremediation in contaminated environments by removing toxic elements (Leduc \& Terry 2005).

Industrial and agricultural procedures are increasing the concentration of heavy metals in the environment. Phosphatic fertilizers and other products used in 
agriculture may increase the level of toxic elements, especially cadmium (Cd) (Satarug et al. 2003, Chien et al. 2003). Even if the levels of Cd do not reach alarming values, the constant use of fertilizers and pesticides can contribute to the presence of this element in soil and water for many years. Besides, the estimated half-life for $\mathrm{Cd}$ in soil varies between 15 and 1,100 years (Alloway 1990).

Cadmium is normally found in association with zinc, and only rarely in pure state, being present in various types of rocks, soils and in water (Aravind \& Prasad 2005). In non-contaminated soils, $\mathrm{Cd}$ is found only in low concentrations from 0.04 to $0.32 \mathrm{mM}$ (Wagner 1993), while in water these values range from 0.001 to $0.01 \mathrm{mg} \mathrm{L}^{-1}$ (World Health Organization 1992). In Brazil Cd concentrations found in some types of soil varies from 0.2 to $1.8 \mathrm{mg} \mathrm{kg}^{-1}$ (Fadigas et al., 2002). The average amount of $\mathrm{Cd}$ in commercial fertilizers in Brazil varies from 1.7 to $46.6 \mathrm{mg} \mathrm{kg}^{-1}$, so that $c a$. 1.30 to 230 . $40 \mathrm{~g} \mathrm{ha}^{-1}$ year ${ }^{-1}$ of Cd could be introduced for the production of the main crops (Amaral-Sobrinho et al. 1992).

Only a small portion of the fertilizers applied to soil is used by the plants, with the portion that is not retained being washed away to water bodies or to the underground, altering their quality (Amaral-Sobrinho et al. 1992). The Brazilian Environmental Council (Conama) allows for $\mathrm{Cd}$ concentrations from 0.001 to $0.2 \mathrm{mg} \mathrm{L}^{-1}$. Concentrations above these values are considered toxic for aquatic communities and improper for human use (MMA 1986).

Regnellidium diphyllum Lind., a heterosporous fern in the Marsileaceae family, has its distribution restricted to Southern Brazil and some adjoining localities in Uruguay and Argentina (Schultz 1949, Alonso-Paz \& Bassagoda 2002). This species have been listed as vulnerable in the endangered species list of the State of Rio Grande do Sul (Sema 2008). It grows in wetlands which in many areas have been transformed in rice fields and pastures.

Considering the lack of information about the sensitivity of Regnellidium diphyllum to the presence of contaminants and due to the conservation status of this species, the germination of megaspores and the initial development of sporophytes in the presence of $\mathrm{Cd}$ was analyzed in vitro in order to establish its tolerance limits to this contaminant as well as the biological responses at these stages of the life-cycle.

\section{Material and methods}

Megaspores of Regnellidium diphyllum were obtained in 2003 from sporocarps of different plants collected in 2000 in the municipality of Triunfo ( $\left.29^{\circ} 48^{\prime} \mathrm{S}, 51^{\circ} 41^{\prime} \mathrm{W}\right)$, in State of Rio Grande do Sul, Brazil, and kept at room temperature (about $25^{\circ} \mathrm{C}$ ). Voucher specimens were placed in the Herbarium of the Universidade do Vale do Rio dos Sinos Unisinos (PACA, São Leopoldo, Brazil). Fifteen sporocarps were washed in tap water, rinsed with $70 \%$ ethanol solution and kept four minutes in a 7\% sodium hypochlorite solution, then washed in sterile distilled water and dried on sterile filter paper. Megaspores were separated manually from the microspores under a stereo-microscope. To assure homogeneous megaspore samples, the material from the different sporocarps was mixed. Considering the normal occurrence of apogamy in megagametophytes of $R$. diphyllum, only megaspores were used, in order to obtain uniform cultures, thus avoiding the mixture of sexual and apogamically formed sporophytes.

As liquid culture medium, Meyer's solution (Dyer 1979) was prepared with different concentrations of $\mathrm{Cd}$, starting with a Titrisol ${ }^{\otimes} 1000 \mathrm{mg} \mathrm{L}^{-1}$ solution of $\mathrm{Cd}$, obtaining the concentration of: $0.39,0.78,1.56,3.12,6.25,12.5,25,50$, $100 \mathrm{mg} \mathrm{L}^{-1}$, and the control treatment without cadmium. The $\mathrm{pH}$ was adjusted to 6.2. Twenty five megaspores were placed in each glass vial $(4.5 \mathrm{~cm} \times 10 \mathrm{~cm})$ with $25 \mathrm{~mL}$ of the solution. Each vial was considered one experimental unit and four repetitions for each treatment were prepared.

The culture vials were distributed randomly in a growth chamber with a photoperiod of 16 hours, under $110 \mu \mathrm{mol} \mathrm{m} \mathrm{m}^{-2} \mathrm{~s}^{-1}$ of PAR (photosynthetically active radiance) at $24 \pm 1{ }^{\circ} \mathrm{C}$. Data were collected after one and four weeks in culture. In order to document the development of the sporophytes, three individuals were taken randomly from each replication at the end of the first and last week. They were measured for the length of the primary root and the length of the primary and secondary leaves. After four weeks the germinated megaspores and the megagametophytes presenting sporophytes were counted. For each treatment the total number of leaves was counted for three individuals from each replication, totalizing a sample of twelve for each treatment. Megaspores presenting at least a globose green structure with a crown of rhizoids were considered germinated.

Megaspore germination and sporophyte formation rates were transformed into percentages. The normality and homogeneity of the germinability were tested using the Kolmogorov-Smirnov (Santana \& Ranal 2004) and the Levene tests. When these assumptions of the parametric statistic were attended, ANOVA and Tukey tests were applied; on the contrary, Kruskal-Wallis and Dunn tests were used to detect statistical differences among treatments $(P<0.05)$. The analyses were conducted using the Systat version 10.2 Windows 2000.

\section{Results}

There was a significant reduction of megaspore germination at cadmium concentrations of $50 \mathrm{mg} \mathrm{L}^{-1}$, while no germination occurred at $100 \mathrm{mg} \mathrm{L}^{-1}$ (figure 1A). 
Cadmium concentrations up to $6.25 \mathrm{mg} \mathrm{L}^{-1}$ did not affect the sporophyte formation in relation to the control treatment, but at $12.5 \mathrm{mg} \mathrm{L}^{-1}$ of $\mathrm{Cd}$ and higher than this an inhibitory effect was observed (figure 1B).
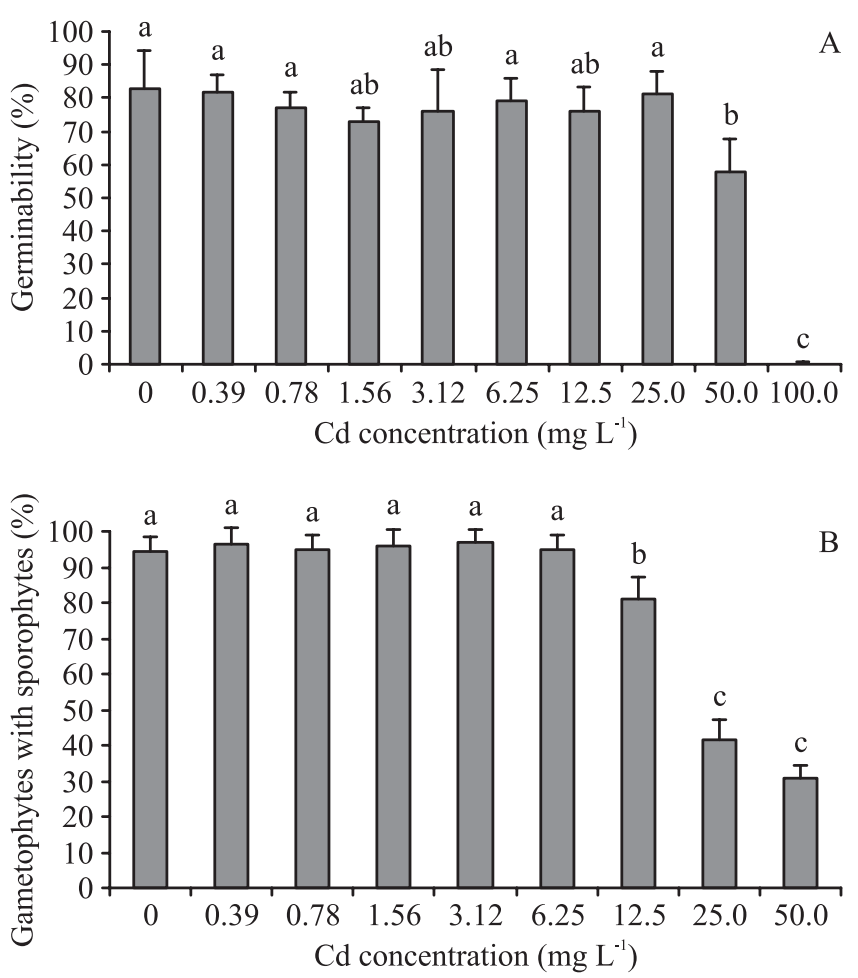

Figure 1. A. Germinability (means \pm standart deviations) $(F=42.256 ; P<0.001, d . f .=9,30 ; n=4 \times 25)$. B. Sporophyte formation (means \pm standart deviations) $(F=100.710 ; P<$ $0.001 ;$ d.f. $=8,27 ; n=4 \times 25$ ) of Regnellidium diphyllum megaspores in different cadmium concentrations after four weeks in culture.

The length of the primary root of the sporophytes was affected by $\mathrm{Cd}$. After one week in culture, a significant reduction in root growth compared to the control was observed at concentrations of $0.78 \mathrm{mg} \mathrm{L}^{-1}$ and higher than this. Similar results could also be observed at the end of four weeks in culture (table 1).

The development of primary and secondary leaves was also affected by the presence of $\mathrm{Cd}$. The growth of the primary leaf was significantly reduced at the end of the first and fourth week, when compared with the control, at Cd concentrations of $12.5 \mathrm{mg} \mathrm{L}^{-1}$ and higher than this. The secondary leaves were shorter than those formed by the control plants in the four week cultures, at a Cd concentration of $0.78 \mathrm{mg} \mathrm{L}^{-1}$ and higher than this. In the treatments with $\mathrm{Cd}$ concentrations of $12.5 \mathrm{mg} \mathrm{L}^{-1}$ and higher than this, the secondary leaf was not formed even after four weeks in culture (table 1).

\section{Discussion}

Previous studies of $\mathrm{Cd}$ toxicity in aquatic macrophytes discussed changes in the permeability of the cellular membrane, interference in the photosynthetic process and reduced growth of the plants. Cadmium inhibits the synthesis of chlorophyll, damages thylakoid structure, inhibits enzymes, interferes with various steps of photosynthesis and induces deficiencies of minerals like iron, thus, influencing negatively metabolic activities of plants (for revision, see Benavides et al. 2005). Growth reduction (roots and leaves/aerial parts) was related to the increase of Cd concentration in Eichhornia crassipes (Mart.) Solms and in the fern Salvinia auriculata Aubl. (Oliveira et al. 2001). Strong phytotoxicity symptoms in floating aquatic macrophytes with the increase of exposure time to $\mathrm{Cd}$ were observed by Maine et al . (2001). In their study, the angiosperms Pistia stratiotes L., Hydromistia stolonifera, E. crassipes and the pteridophyte Salvinia herzogii Sota presented chlorosis and in part necrosis of the plants when in contact with up to $6 \mathrm{mg} \mathrm{L}^{-1}$ of this heavy metal, especially during the first 24 hours of exposure.

Several studies related to the growth of plants in the presence of $\mathrm{Cd}$ indicate that the root is the plant organ that presents more intense symptoms of toxicity. Most authors cite the large capacity of roots to accumulate $\mathrm{Cd}$ in their tissues and the reduced growth of these structures in the presence of this contaminant (Fargasová 2001, Maine et al. 2001, Youn-Joo 2004). Furthermore, among the heavy metals, $\mathrm{Cd}$ is most easily translocated from roots to leaves, influencing the development of the aerial parts of the plant (Alloway 1990).

Some studies call attention to the interaction of $\mathrm{Cd}$ with other metals, especially zinc (Aravind \& Prasad 2005), as well as with calcium. Cadmium may substitute $\mathrm{Ca}$ on the calcium-specific protein calmodulin and affect other physiological processes that regulate the absorption of Ca by the cells (World Health Organization 1992). These data, when compared with the present results, could explain the reduction of the germinability and the lower number of megagametophytes presenting sporophytes. The toxic effect of $\mathrm{Cd}$ could inhibit the absorption of Ca necessary for cellular divisions, thus, negatively influencing the germination process and the development of sporophytes. In another experiment by the present authors with Regnellidium diphyllum, no sporophyte development occurred in the absence of $\mathrm{Ca}$ (D. A. Wunder, unpublished data).

Usually, the secondary leaf is formed after one week in culture (Vianna 1973). However, in the present study, 
Table 1. Regnellidium diphyllum growth (length mean \pm standart deviation of primary root, primary leaf and first secondary leaf) after one and four weeks in culture at different concentrations of cadmium. Different letters denote statistical differences among treatments (Kruskal-Wallis test for $H$; Dunn test $P<0.05$. ANOVA test for $F$; Tukey test $P<0.05$ ). CC: cadmium concentration.

\begin{tabular}{|c|c|c|c|c|c|c|}
\hline \multirow{2}{*}{$\begin{array}{c}\mathrm{CC} \\
\left(\mathrm{mg} \mathrm{L}^{-1}\right)\end{array}$} & \multicolumn{2}{|c|}{ Primary root $(\mathrm{mm})$} & \multicolumn{2}{|c|}{ Primary leaf $(\mathrm{mm})$} & \multicolumn{2}{|c|}{ First secondary leaf $(\mathrm{mm})$} \\
\hline & 1 week & 4 weeks & 1 week & 4 weeks & 1 week & 4 weeks \\
\hline 0.00 & $7.33 \pm 1.37 \mathrm{a}$ & $\pm 1.20 \mathrm{a}$ & $8.83 \pm 2.16 \mathrm{a}$ & $10.75 \pm 1.48 \mathrm{a}$ & $1.25 \pm 0.50 \mathrm{a}$ & $16.75 \pm 2.75$ \\
\hline 0.39 & $6.08 \pm 1.50 \mathrm{ab}$ & $6.83 \pm 1.52 \mathrm{a}$ & $8.41 \pm 0.90 \mathrm{a}$ & $10.41 \pm 1.44 \mathrm{a}$ & $0.83 \pm 0.34 \mathrm{ab}$ & $17.50 \pm 1.29 a$ \\
\hline 0.78 & $4.25 \pm 1.42 \mathrm{~b}$ & $3.0 \pm 0.85 \mathrm{~b}$ & $6.41 \pm 2.06 \mathrm{a}$ & $9.33 \pm 2.14 \mathrm{a}$ & $1.08 \pm 0.64 \mathrm{a}$ & $11.25 \pm 0.96 \mathrm{~b}$ \\
\hline 1.56 & $3.08 \pm 0.99 \mathrm{bc}$ & $\pm 0.90 \mathrm{bc}$ & $7.75 \pm 1.48 \mathrm{a}$ & $9.33 \pm 2.34 \mathrm{a}$ & $1.16 \pm 0.58 \mathrm{a}$ & $\pm 2.16 \mathrm{~b}$ \\
\hline 3.12 & $2.08 \pm 0.66 \mathrm{bc}$ & $1.66 \pm 0.65 \mathrm{bcd}$ & $7.50 \pm 2.35 \mathrm{a}$ & $7.58 \pm 2.53 \mathrm{ab}$ & $0.87 \pm 0.16 \mathrm{a}$ & $6.25 \pm 2.06 c$ \\
\hline 6.25 & $1.91 \pm 0.90 \mathrm{bcd}$ & $1.25 \pm 0.45 \mathrm{~cd}$ & $5.0 \pm 1.41 \mathrm{a}$ & $5.58 \pm 3.28 a b c$ & $0.46 \pm 0.16 \mathrm{ab}$ & $4.00 \pm 1.41 \mathrm{c}$ \\
\hline 12.50 & $0.79 \pm 0.25 \mathrm{~cd}$ & $0.87 \pm 0.31 \mathrm{~d}$ & $1.29 \pm 0.54 \mathrm{~b}$ & $1.33 \pm 0.49 \mathrm{c}$ & $0.0 \mathrm{~b}$ & $0.0 \mathrm{c}$ \\
\hline 25.00 & $0.12 \pm 0.22 \mathrm{~d}$ & $0.41 \pm 0.51 \mathrm{de}$ & $0.16 \pm 0.32 \mathrm{c}$ & $0.41 \pm 0.51 \mathrm{c}$ & $0.0 \mathrm{~b}$ & 0.0 \\
\hline 50.00 & $0.04 \pm 0.14 \mathrm{~d}$ & $0.08 \pm 0.19 \mathrm{e}$ & $0.04 \pm 0.14 \mathrm{c}$ & $0.12 \pm 0.31 \mathrm{c}$ & $0.0 \mathrm{~b}$ & 0.0 \\
\hline & $H=33.288$ & $H=33.628$ & $H=31.224$ & $H=30.965$ & $F=8.577$ & $F=82.835$ \\
\hline & d.f. $=8,27$ & d.f. $=8,27$ & d.f. $=8,27$ & d.f. $=8,27$ & d.f. $=8,27$ & d.f. $=8,27$ \\
\hline & $P<0.001$ & $P<0.001$ & $P<0.001$ & $P<0.001$ & $P<0.001$ & $P<0.001$ \\
\hline
\end{tabular}

the secondary leaf was not formed in the treatments with Cd concentrations of $12.5 \mathrm{mg} \mathrm{L}^{-1}$ and higher than this. Salvinia molesta presents low tolerance to $\mathrm{Cd}$ concentrations higher than $0.1 \mathrm{mg} \mathrm{L}^{-1}$, and the growth and development of new leaves is negatively affected with the increase in concentration or exposure time (Gupta \& Devi 1992). For S. molesta Mitchell, the presence of $\mathrm{Cd}$ in the medium affect the availability of nutrients such as calcium, magnesium, zinc and potassium, thus reducing the formation of new branchlets and the biomass of the new structures even in a Cd-free medium after being exposed to this heavy metal (Outridge \& Hutchinson 1990).

If contaminants with $\mathrm{Cd}$ concentrations higher than $0.78 \mathrm{mg} \mathrm{L}^{-1}$ reach plants in initial stages of sporophyte development, this would probably impede the establishment of the species. The constant use of agricultural supplies contaminated by $\mathrm{Cd}$ may represent an additional threat to Regnellidium diphyllum that occurs in a region intensely affected by agricultural activities. The tolerance of this species to $\mathrm{Cd}$ far above concentrations found in natural environments suggests that investigations of the eventual capacity of $R$. diphyllum plants to absorb and accumulate cadmium may produce interesting results.

Acknowledgements - The authors are thankful to the Universidade do Vale do Rio dos Sinos for the use of laboratories and scholarship to the first author, to the Centro
Universitário Feevale, to the Universidade Federal do Rio Grande do Sul and to the Conselho Nacional de Desenvolvimento Científico e Tecnológico (CNPq) for support and grants.

\section{References}

ALLOWAY, B.J. 1990. Cadmium. In Heavy metals in soils (B.J. Alloway, ed.). Chapman \& Hall, London, p. 100-150.

ALONSO-PAZ, E. \& BASSAGODA, M.J. 2002. Revisión de las Marsileaceae del Uruguay y primera cita de Pilularia americana A. Braun. Comunicaciones Botanicas - Museos Nacionales de Historia Natural y Antropologia 125:1-8.

AMARAL-SOBRINHO, N.M.B., COSTA, L.M., OLIVEIRA, C. de \& VELLOSO, A.C.X. 1992. Metais pesados em alguns fertilizantes e corretivos. Revista Brasileira de Ciência do Solo 16:271-276.

ARAVIND, P. \& PRASAD, M.N.V. 2005. Cadmium-Zinc interactions in a hydroponic system using Ceratophyllum demersum L.: adaptative ecophysiology, biochemistry and molecular toxicology.

BENAVIDES, M.P., GALLEGO, S.M. \& TOMARO, M.L. 2005. Cadmium toxicity in plants. Brazilian Journal of Plant Physiology 17:21-34.

CHIEN, S.H., CARMONA, G., PROCHNOW, L.I. \& AUSTIN, E.R. 2003. Cadmium avaibility from granulated and bulk-blended phosphate-potassium fertilizers. Journal of Environmental Quality 32:1911-1914. 
DYER, A.F. 1979. The culture of fern gametophytes for experimental investigation. In The experimental biology of fern (A.F. Dyer, ed.). Academic Press, London, p.253-291.

ESPÍNDOLA, E.L.G., BRANCO, M.B.C., FRACÁCIO, R., GUNTZEL, A.M.; MORETTO, E.M., PEREIRA, R.H.G., RIETZLER, A.C., ROCHA, O., RODGHER, S., SMITH, W.S. \& TAVARES, K.S. 2003. Organismos aquáticos. In Fragmentação de ecossistemas: causa, efeitos sobre a biodiversidade e recomendações de políticas públicas - biodiversidade 6 (D.M. Rambaldi \& D.A.S. de Oliveira, eds.). MMA/SBF, Brasília, p.201-238.

FADIGAS, F. de S., AMARAL-SOBRINHO, N.M.B. do., MAZUR, N., ANJOS, L.H.C. dos \& FREIXO, A.A. 2002. Concentrações naturais de metais pesados em algumas classes de solos brasileiros. Bragantia 61: 151-159.

FARGASOVÁ, A. 2001. Phytotoxic effects of Cd, Zn, Pb, $\mathrm{Cu}$ and $\mathrm{Fe}$ on Sinapis alba L. seedlings and their accumulation in roots and shoots. Biologia Plantarum 44:471-473.

GUPTA, M. \& DEVI, S. 1992. Cadmium sensitivity inducing structural responses in Salvinia molesta Mitchell. Bulletin of Environmental Contamination and Toxicology 49:436-443.

LEDUC, D.L. \& TERRY, N. 2005. Phytoremediation of toxic trace elements in soil and water. Journal of Industrial Microbiology and Biotechnology 32:514-520.

MAINE, M.A., DUARTE, M.V. \& SUÑ̃E, N.L. 2001. Cadmium uptake by floating macrophytes. Water Research 35:2629-2634.

MMA. 1986. Resolução Conama no 20. Ministério do Meio Ambiente, Brasília.
OLIVEIRA, J.A., CAMBRAIA, J., CANO, M.A.O. \& JORDÃO, C.P. 2001. Absorção e acúmulo de cádmio e seus efeitos sobre o crescimento relativo de plantas de aguapé e de salvínia. Revista Brasileira de Fisiologia Vegetal 13:329-341.

OUTRIDGE, P.M. \& HUTCHINSON, T.C. 1990. Effects of cadmium on integration and resource allocation in the clonal fern Salvinia molesta. Oecologia 84:215-223.

SANTANA, D.G. \& RANAL, M.A. 2004. Análise da germinação: um enfoque estatístico. UNB, Brasília.

SATARUG, S., BAKER, J.R., URBENJAPOL, S., HASWELLELKINS, M., REILLY, P.E.B., WILLIAMS, D.J. \& MOORE, R. 2003. A global perspective on cadmium pollution and toxicity in non-occupationally exposed population. Toxicology Letters 137:65-83.

SCHULTZ, A.R. 1949. Contribuições ao conhecimento de Regnellidium diphyllum Lindman. Lilloa 17: 139-144.

SEMA. 2008. Espécies da flora ameaçadas de extinção do Rio Grande do Sul. Secretaria do Meio Ambiente, Porto Alegre.

VIANNA, E.C. 1973. Observações sobre o desenvolvimento morfológico do esporófito de Regnellidium diphyllum Lindm. (Hydropteridineae). Iheringia. Série Botânica 18:27-37.

WAGNER, G.J. 1993. Accumulation of cadmium in crop plants and its consequences to human health. Advances in Agronomy 51:173-212.

WORLD HEALTH ORGANIZATION (WHO). 1992. Cadmium: environmental health criteria. Who Geneva.

YOUN-JOO, A. 2004. Soil ecotoxicity assessment using cadmium sensitive plants. Environmental Pollution 127:21-26. 